\title{
Jerzy Bralczyk, Jan Miodek, Andrzej Markowski, Jerzy Sosnowski, Wszystko zależy od przyimka. Bralczyk, Miodek, Markowski $w$ rozmowie $z$ Jerzym Sosnowskim, Wydawnictwo Agora, Warszawa 2014,
} ss. 286

Autorzy książki Wszystko zależy od przyimka - Jerzy Bralczyk, Jan Miodek, Andrzej Markowski i Jerzy Sosnowski - zrealizowali na jej stronach pomysł bardzo odważny, oryginalny, a można nawet pokusić się o stwierdzenie, że odrobinę szalony. Trzej słynni językoznawcy zdecydowali się na cykl spotkań, podczas których wymieniali poglądy na temat współczesnej polszczyzny. Moderatorem ich dyskusji został znany publicysta i dziennikarz, próbujący z różnym skutkiem - jak sam przyznaje we Wstępie - zapanować nad „krasomówczą swadą" profesorów (s. 7). Efektem tych rozmów jest książka właściwie nie tyle napisana, ile „powiedziana”: w formie przypomina zapis audycji radiowej, a taka propozycja jest - co wypada zaznaczyć - wyjątkowo atrakcyjna dla odbiorcy.

Tom składa się z 13 rozdziałów (każdy z nich stanowi osobną jednostkę tematyczną) poświęconych zagadnieniom z zakresu kultury języka. Autorzy wielokrotnie podkreślają, że dyscyplina ta obejmuje nie tylko kwestie poprawnościowe, ale i najnowsze tendencje widoczne w polszczyźnie, a także a może przede wszystkim - stwarzane przez język polski możliwości, „które bywają pokusami, ale stanowią też szansę" (s. 7). Poruszane przez językoznawców problemy są niezwykle aktualne, a opowiada się o nich w sposób prosty i swobodny, dzięki czemu pozycja ta zainteresuje każdego miłośnika polszczyzny.

W rozdziale pierwszym, Etykieta $i$ netykieta $z$ przecinkiem $w$ tle, czytelnik znajdzie m.in. dyskusję o e-mailowych formułach powitalnych (w tym odpowiedź na pytanie, dlaczego internauci - szczególnie ci młodsi - wybierają formuły witam, witaj zamiast Szanowny Panie i Szanowna Pani), o przyczynach niedbałości interpunkcyjnej w internecie czy też o medialnej modzie na 
mówienie do wszystkich rozmówców na „ty”, niezależnie od ich wieku czy stanowiska. Wśród rozważań o grzeczności językowej pojawia się istotna myśl Bralczyka: „Kulturoznawcy uważają, że działa tutaj reguła wahadła. Że są okresy, w których bardzo silnie przestrzega się pewnych rygorów i ma się je niejako wkodowane gdzieś głęboko, a potem przychodzą wahnięcia w drugą stronę. I wtedy jest wszystko jedno jak, byleby wiadomo było - co. [...] Myślę, że teraz wahadło wędruje w stronę reguł. Tyle tylko, że kiedyś reguły dotyczyły przede wszystkim sposobu bycia wśród ludzi, a dziś zaczynają one mieć charakter ekonomiczny: jeśli chcesz osiągnąć sukces, to powinieneś się zachowywać, mówić tak i tak" (s. 18).

W części kolejnej (o znamiennym tytule Dlaczego nie lubimy mówić o wulgaryzmach) językoznawcy zgodnie przyznają, że pytania o jednostki objęte tabu wzbudzają ich niechęć. Niejednokrotnie bowiem ich wypowiedzi stawały się źródłem sensacji, o czym mówi Markowski: „To temat łatwy, a jednocześnie pozwala bezkarnie opublikować kilka wulgaryzmów, co zwiększy atrakcyjność publikacji. Wystarczy $k$ i cztery kropki, a i tak wiadomo, o co chodzi. I jeszcze tytuł: «Miodek mówił o k...»" (s. 54). Profesorowie zwracają tu uwagę, że posłużenie się wulgaryzmem nie jest błędem językowym, ale kulturowym. Źródeł wszechobecnego zjawiska wulgaryzacji natomiast doszukują się w okresie transformacji systemowej - jak tłumaczy Miodek: „Niektórzy mówili: Widzisz? To jest zasługa demokracji. Teraz wszystko wolno. To była jedna interpretacja. A druga: nie, to wszystko wina komuny. To wtedy naród się zwulgaryzował, tylko to wszystko było ukryte, a teraz przyszła wolność i wylazło, co najgorsze. Jak było naprawdę? Chyba nigdy do tego nie dojdziemy" (s. 61).

W rozdziale pt. Ja się deklinuję! wyczerpująco omówiono fenomen nieodmieniania polskich nazwisk (który uznaje się za rażący błąd wtedy, jeśli odmienianie nazwiska nie powodowałoby żadnych nieporozumień komunikacyjnych). Bralczyk, Miodek i Markowski wśród jego przyczyn wymieniają działanie tendencji do ujednoznaczniania oraz potrzebę traktowania nazwiska jako ważnego elementu autoidentyfikacji, niemalże magicznej etykietki (s. 67). Przy tej okazji autorzy przypominają również podstawowe zasady odmiany imion i nazwisk (polskich i obcych) oraz tworzenia - coraz rzadszych - nazwisk odojcowskich i odmężowskich.

Na początku rozdziału czwartego (Język w stużbie reklamy) Bralczyk zastrzega: „Na temat języka reklamy kiedyś napisałem całą książkę. Ale to były czasy, kiedy można było jeszcze odnajdywać jakieś prawidła, jakieś reguły, jakieś wątki czy tendencje. Teraz w reklamie można absolutnie wszystko" (s. 90). Badacze starają się uwypuklić, że w języku tekstów reklamowych zdarzają się odchylenia od normy: albo w stronę błędu, albo w stronę poezji, co w jednym i drugim przypadku może skutkować swoistą „zaraźliwością” 
reklamy - wszak stała się ona nowym wspólnym kodem kulturowym, takim, jakim wcześniej była literatura.

Pytaniem Do you speak Polish? rozpoczyna się rozmowa o zalewie zapożyczeń angielskich w języku polskim. Rozmówcy przywołują więc modne neosemantyzmy (dietę w zn. 'sposób odżywiania', kondycję - 'stan' czy dedykowany - 'przeznaczony'), kalki (doktadnie - mimo trafnej argumentacji Bralczyka przedstawiającej zasadność używania tego zapożyczenia w znaczeniu 'właśnie tak' - uznano za „nieznośne stylistycznie”) i szczególnie niepokojący fakt, że słownictwa z niektórych dziedzin życia nawet nie tłumaczy się na język polski. Profesorowie zwracają uwagę także na pretensjonalność i snobizm niektórych zachowań (np. gdy w restauracji zamiast zakasek możemy zamówić jedynie startery) - podkreślają „,wielką siłę stylistyczną” wtrętu obcojęzycznego, którym nigdy nie powinno się epatować.

Rozdział szósty - Ja panu nie przerywałem - dotyczy agresji językowej, także tej dostrzegalnej w języku polityki. O akceptacji zachowań agresywnych Bralczyk wypowiada się następująco: „Ekspansja agresji łączy się z funkcjonalizacją naszego języka, także języka publicznego: ten język ma być przede wszystkim skuteczny, ma do czegoś zachęcać. A wydaje się, że będzie skuteczniejszy, jeśli będzie wyrazisty. A wyrazisty oznacza dziś brutalny" (s. 131). Językoznawcy przekonują, że nie warto popełniać językowych niestosowności, ale jednocześnie - co ciekawe - oceniają określenie język nienawiści jako zbyt nacechowane, by mogło stać się terminem naukowym.

Następnym tematem do dyskusji stał się język środowisk młodzieżowych (rozdział Polewka z suchara) charakteryzujący się trafną metaforyką i twórczym podejściem do płaszczyzny językowej (s. 141). Choć z założenia slang powstaje po to, by ludzie spoza pewnego kręgu go nie rozumieli i nie używali, polskie media starają się za pomocą slangu nawiązać kontakt z odbiorcą, a jak komentuje Bralczyk - „Jeśli starają się, to już jest niedobrze. To jest trochę tak, jak w przepisach dawnej retoryki. Kiedy widać było, że ktoś zna retorykę, już był przegrany. Sztuką jest ukrycie sztuki! Sztuką jest pokazywanie, że się człowiek nie stara albo niepokazywanie, że człowiek się stara" (s. 151). A co z sytuacją, gdy użytkownik języka świadomie i umiejętnie posługuje się różnymi odmianami stylowymi polszczyzny? Markowski sugeruje, by podczas zabawy w ,zderzenia stylistyczne” zawsze brać pod uwagę to, do kogo mówimy (s. 154).

Kolejną rozmowę opatrzono tytułem Dżender ministry - i paradoksalnie w tym właśnie rozdziale wyszła na jaw „męskocentryczność” polskiej gramatyki (okazało się, jak trudno utworzyć równoznaczne kobiece odpowiedniki od takich nazw zawodów jak detektyw, stolarz czy drukarz). Przy innych wyrazach Bralczyk zastrzega nawet, że „Najlepiej byłoby uznać, że słowa takie jak 
prezydent czy premier są przede wszystkim nazwami godności albo nazwami stanowisk, a nie mężczyzn, którzy je sprawują" (s. 166). Dodatkowo czytelnik znajdzie w tej części krótką historię kariery wyrazu gender - nadużywanego, a w końcu ośmieszonego.

Rozdział Polityczny z waści kawaler jest tematycznie zbliżony do poprzedniego: omówiono w nim zachowania językowe z kręgu tzw. ,poprawności politycznej”, którą Bralczyk, Markowski i Miodek słusznie proponują zamienić np. na ,poprawność obyczajową", bo „w «poprawności politycznej» chodzi nie o to, by nie mówić źle o lewicy, prawicy czy jakiejś partii, tylko o to, żeby mówić tak, aby nikogo nie urazić" (s. 179). Wszyscy uczestnicy dyskusji poddają wnikliwej analizie wyrazy z rozmaitych względów uznane za „niepożądane”, takie jak Murzyn, Cygan, żyd, angol, pedat, homik, komuch czy pisior.

W części poświęconej problemowi zmian zachodzących w polszczyźnie (To żyje!) przywołano dwie metafory, którymi próbowano odzwierciedlić specyfikę języka: czyli metaforę ogrodu oraz rzeki z wieloma dopływami. Według autorów książki Wszystko zależy od przyimka o kształcie języka polskiego za kilkadziesiąt lat zdecydują dominujące tendencje zewnętrznojęzykowe (a więc dopływy), czyli anglicyzacja i internacjonalizacja. Bralczyk przewiduje, że (za kilkaset lat) wskutek internacjonalizacji języki narodowe będą wręcz lokalnymi odmianami języka ponadnarodowego, uniwersalnego. Podczas tej rozmowy odniesiono się również do przepisów ortograficznych, m.in. do ujednolicenia pisowni partykuły nie z imiesłowami przymiotnikowymi oraz do kłopotów związanych z zasadą regulującą pisownię nazw miejscowości typu Rabka-Zdrój, Ladek-Zdrój.

W rozdziale Poderwać białogłowe językoznawcy - powołując się na Aleksandra Wilkonia - zgadzają się, że podstawową opozycją stylową współczesnej polszczyzny jest para oficjalność - nieoficjalność. Odpowiadają tu także na pytania: kogo współcześnie moglibyśmy uznać za autorytet stylistyczny, jaki język kryje się za sformułowaniem „elegancki styl potoczny”, jak uczyć porozumiewania się za pomocą różnych odmian stylistycznych.

Zagadnienia dydaktyki języka polskiego w szkole poruszono także w rozmowie pt. Jak uczyć i po co uczyć. Pośród pomysłów mających zainteresować uczniów wiedzą o języku pojawiają się: nauka korzystania ze źródeł (np. z danych korpusowych i słowników), pokazywanie europejskiej wspólnoty językowej, a nawet wykład o języku jako systemie znaków zamiast tradycyjnej lekcji gramatyki czy ortografii. Profesorowie zastanawiają się, czy nie lepiej byłoby uczyć w szkole świadomości, a nie poprawności językowej - Miodek stwierdza zresztą, że „Świadome igranie z normą jest jedną z największych przyjemności stylistycznych" (s. 232), co na pewno mogłoby uatrakcyjnić niejedne zajęcia. 
Rozdział ostatni - Między Szczekocinami a Mszczonowem, czyli za co kochamy język polski - przeznaczono na dyskusję o (ogólnych, wybranych raczej subiektywnie) zaletach i wadach polszczyzny. Bralczyk, Miodek i Markowski pozytywnie oceniają polskie słowotwórstwo i swobodny szyk zdania, a negatywnie - dużą liczbę końcówek w jednym przypadku fleksyjnym oraz bogactwo systemu spółgłoskowego. Językoznawcy zastanawiają się także, z czego wynika coraz częściej spotykana intonacja pytająca w zdaniach twierdzących i upodobanie młodych dziewcząt do zamiany szeregu [ś], [́́], [ć], [dź] w [s'], [z'], [c'], [dz']. Na zakończenie zaznaczają, że współczesna troska Polaków o kulturę języka wiąże się z pamięcią o XIX wieku i ówczesnym zagrożeniu polszczyzny.

Nie sposób przywołać tu wszystkich omówionych zagadnień ani streścić cennych anegdot i opowieści. Książka Wszystko zależy od przyimka ma charakter wyraźnie popularnonaukowy, co jednak nie ujmuje jej wartości. Z pewnością może być wykorzystywana jako materiał dydaktyczny na zajęciach, zarówno przez nauczycieli szkolnych, jak i akademickich (dlatego przy kolejnym wydaniu warto byłoby dołączyć indeks zanalizowanych form i połączeń wyrazowych). Co ważne, autorom udało się osiągnąc chyba najtrudniejszy z zakładanych celów: w piękny sposób pokazali, że o języku można nie tylko mówić, ale i czytać dla przyjemności. 